\title{
The Bushman Maxillary Canine of the Chewa Tribe in East-Central Africa
}

\author{
Masashi SAKUMA ${ }^{1)}$, Joel D. IRISH ${ }^{2)}$ and Donald H. MORRIS ${ }^{2)}$ \\ 1) Department of Oral Anatomy, Kagoshima University Dental School \\ 2) Department of Anthropology, Arizona State University
}

\begin{abstract}
The expression of the Bushman Canine dental trait among the Chewa tribe of East-Central Africa is described and compared with that of other African populations. Dental hard stone casts were obtained from 82 males and 76 females, and the trait was scored using the Arizona State University dental plaque system. No significant sexual dimorphism in the occurrence of the trait was found according to the chi-square test. The frequency of the Bushman Canine in the Chewa is markedly lower than that in a sample of San (Bushman) from Botswana. This helps support the view that the San represent either an ancestral or perhaps a different stock of people in comparison to other sub-Saharan Africans. When comparing the Chewa with a Central Sotho sample from South Africa, it appears that a gradient of the trait's frequency exists with decreasing expression from south to north. This gradient is probably caused by admixture between San and other peoples (mainly Bantuspeakers) who may not have originally possessed the trait. These findings agree with the so-called "Bantu-expansion" model proposed by several workers.
\end{abstract}

Key Words Dental anthropology, Bushman Canine, Chewa tribe, East-Central Africa, Bantu-expansion

\section{Introduction}

The Bushman Canine is characteristically premolariform due to the great development of the internal cingulum. This trait was first described by ORANJE (1934). Three years later, GALLOWAY (1937) reported in his study of the skeletal remains of Mapungubwe, that such teeth were specialized manifestations of the 'Bushman' (San) dentition. Most recently, MORRIS (1975) studied the prevalence of the trait in a San sample, and compared these findings with the incidence in other African aboriginal populations. $\mathrm{He}$ also coined the term 'Bushman Canine' to describe this dental morphological variant. Beyond this, information dealing specifically with this trait in African populations is rare.

The purpose of this communication is to describe and determine the frequency of the Bushman Maxillary Canine in a sample of living Chewa from East-Central Africa. These findings will then be compared with that of modern San and Central Sotho (Bakoni and Batau tribes) populations from southern Africa.

Article No. 9120 Received July 24, 1991 


\section{Materials and Methods}

The dental hard stone casts used in the present study were made from full-mouth alginate impressions. These dental impressions were collected during 1984-1985 at the dental department of Zomba General Hospital, Malawi in East-Central Africa (Fig. 1). The sample consists of 158 individuals ( 82 males and 76 females) from the Chewa tribe, the largest tribe presently living in Malawi. According to CoON (1962), the Chewa are classified as belonging to the Congoid race. MURDOCK (1959) regards the tribe as linguistically belonging to the Central Bantu-speaking cluster, whereas GREENBERG (1963) places them in the Niger-Congo language family. The individuals in the sample ranged in age from 10 to 34 years, with an average age of 21 years for the males and 20 years for the females (Table 1). Youthful individuals were selected in order to minimize the effects of caries, attrition, or dental calculus on the dentition.

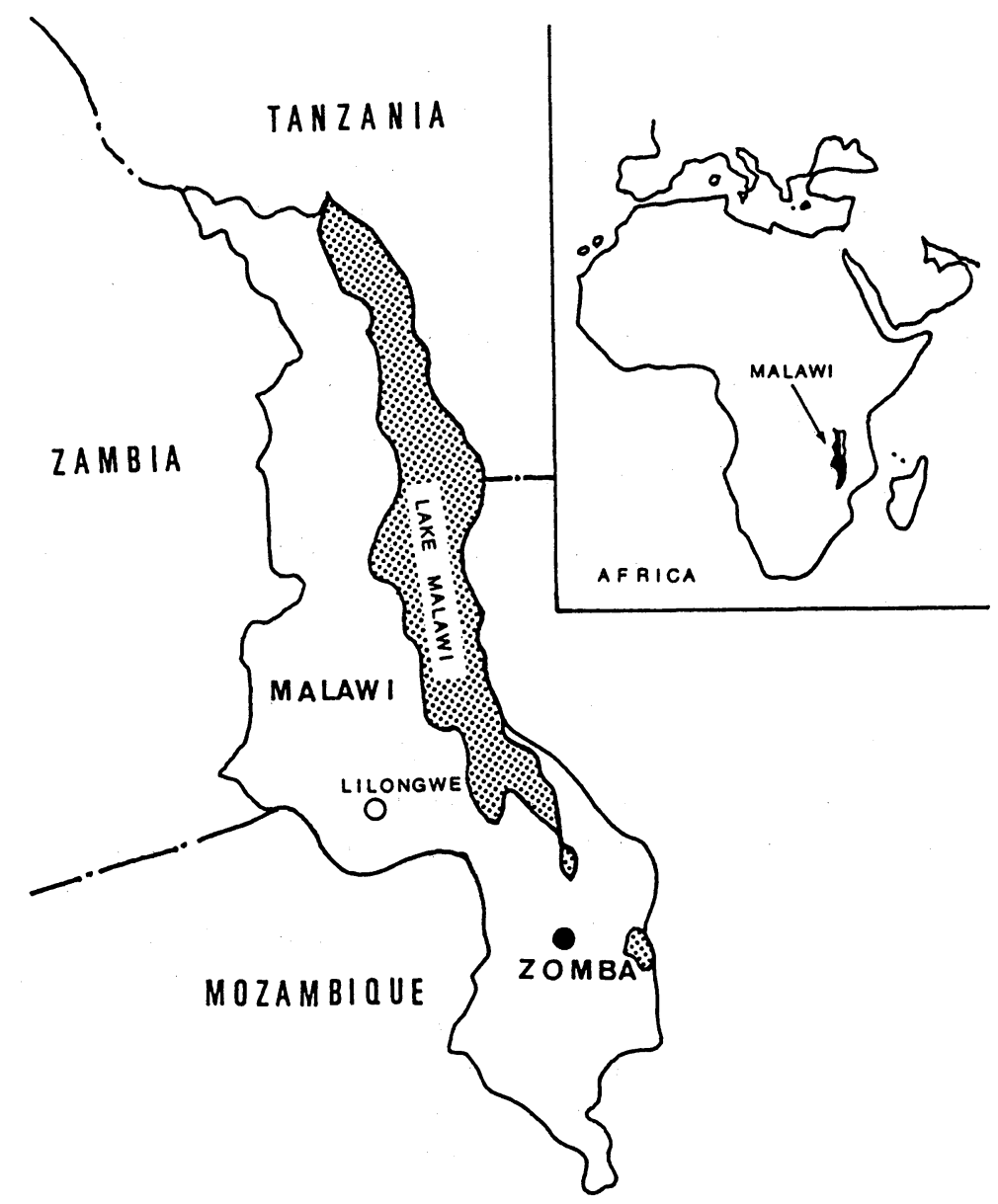

Fig. 1. Map of Malawi, showing the location of Zomba from which the materials were obtained. 
Table 1. The age and sex distribution of the Chewa sample

\begin{tabular}{crcr}
\hline Age (years) & Males & Females & $\%$ \\
\hline $10-14$ & 9 & 9 & 8.9 \\
$15-19$ & 19 & 23 & 26.6 \\
$20-24$ & 38 & 31 & 43.7 \\
$25-29$ & 16 & 11 & 11.2 \\
$30-34$ & 4 & 2 & 3.8 \\
\hline
\end{tabular}

The classifications of the Bushman Canine were based on the standard reference plaque (Fig. 2) for permanent teeth in the Arizona State University system (TURNER et al., 1991). The criteria for classification of the development of the trait can be briefly recapitulated as follows: Grade 0: Mesial and distal lingual ridges are the same size. Neither is attached to the tuberculum dentale if present.

Grade 1: Mesiolingual ridge is larger than the distolingual, and is weakly attached to the tuberculum dentale.

Grade 2: Mesiolingual ridge is larger than the distolingual, and is moderately attached to the tuberculum dentale.

Grade 3: MORRIS's type form. Mesiolingual ridge is much larger than the distolingual, and is fully incorporated into the tuberculum dentale.

The present study follows the precedence set by TURNER and SCOTT (1977) regarding dental trait asymmetry. When a trait is not bilaterally symmetrical, only the higher expression is recorded for analysis. Otherwise scoring both sides unjustly inflates the sample size. The highest score, rather than scoring one particular side, is used because it is assumed that it represents the greatest expression of the genetic potential of the trait for that individual. The weaker expression of the opposite side is felt to represent some inhibition of the expression due to developmental or environmental disturbances (VAN VALEN, 1962). Consequently, the procedure for ranking individuals was to score each individual on both sides. In the case of antimere asymmetry, the value of the side with the highest grade was used as the score for the individual.

Chi-squared analysis was applied to the data with regards to potential sexual dimorphism. The chi-squared values were calculated with the aid of micro-computer (NEC-9801VM) using the BASIC programs named TINDEP (WAKIMOTO et al., 1984).

\section{Results}

All individuals were re-scored five weeks after the original analysis in order to check for internal consistency. The result was a $96.8 \%$ gradewise concordance rate. All individuals classified differently in the second scoring varied by only one grade from the original score. The effect of this error appears to be minimal and random.

Additionally, it is important to ascertain the level of interobserver error to determine whether or not observations made by different individuals are comparable. Sixty individuals that were originally scored by one observer (J. IRISH) were scored by a second observer (D. MORRIS). The result was that three out of 60 individuals were classified differently. None of these differences were greater than one grade apart. Accordingly, the low level of error between two different observers suggests that data collected by different individuals may be comparable when using the standardized reference plaque.

Table 2 depicts the distribution of the different phenotypic grades of expression of the Bushman Maxillary Canine in the Chewas by sex. The absence of sexual dimorphism in the trait is shown by the lack of a statistically significant difference between its incidence in males and females $\left(\chi^{2}=1.041\right.$ with d.f. $=1,0.25>\mathrm{P}>$ $0.20)$. Because of this, the sexes were pooled. This 


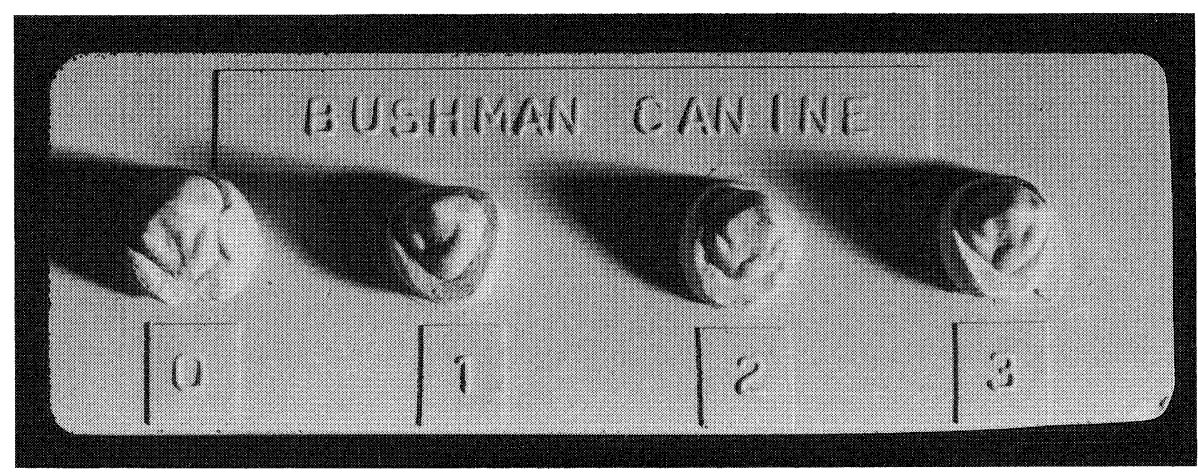

Fig. 2. ASU standard reference plaque of the Bushman Canine (TURNER et al., 1991).

Table 2. Frequency and degree of expression of the Bushman Canine in Chewa

\begin{tabular}{|c|c|c|c|c|c|c|c|c|c|}
\hline \multirow{2}{*}{ Sex } & \multirow{2}{*}{$\mathrm{N}$} & \multicolumn{2}{|c|}{ Grade 0} & \multicolumn{2}{|c|}{ Grade 1} & \multicolumn{2}{|c|}{ Grade 2} & \multicolumn{2}{|c|}{ Grade 3} \\
\hline & & $\mathrm{n}$ & $\%$ & $\mathrm{n}$ & $\%$ & $\mathrm{n}$ & $\%$ & $\mathrm{n}$ & $\%$ \\
\hline Male & 82 & 75 & (91.5) & 3 & (3.7) & 3 & (3.7) & 1 & (1.2) \\
\hline Female & 76 & 73 & (96.1) & 0 & $(0.0)$ & 2 & (2.6) & 1 & (1.3) \\
\hline Total & 158 & 148 & (93.7) & 3 & (1.9) & 5 & (3.2) & 2 & (1.3) \\
\hline
\end{tabular}

$\mathrm{N}$ : Total numbers of observable individuals.

$\mathrm{n}$ : Numbers of individuals demonstrating indicated degree of expression.

Classification was adapted from ASU dental anthropology system (TURNER et al. 1991).

combined data is also shown in Table 2, and is used throughout the remainder of this paper.

Complete absence of the trait (Grade O) occurred in $93.7 \%$ of the sample. The frequencies of the tuberculum dentale weakly (Grade 1) and moderately (Grade 2 ) joining the mesiolingual ridge were $1.9 \%$ and $3.2 \%$, respectively. Lastly, the greatest degree of expression, where the tuberculum dentale strongly joins the mesiolingual ridge (Grade 3 ) occurred in $1.3 \%$ of the sample. In short, when present the Bushman Canine was most commonly found to manifest itself in the middle grade.

\section{Discussion}

The purpose of this paper is to provide further basic data on the Bushman Canine for comparative study within African populations. However, it also focuses on the sexual dimorphism of the Bushman Canine. The level of sexual dimorphism has been assessed. If significant sexual dimorphism exists for a trait, then the two sexes should not be pooled in any analyses, and individuals of unknown sex should not be used. If it does not exist, then sex may be ignored for interpopulation comparisons. As was already noted, chi-squared analysis was used to test for sexual dimorphism for the trait. 
Although the frequency of each grade in the males slightly exceeded that in the females, no evidence of sexual dimorphism was proved under the significance level of $5 \%$.

It was also decided to determine the level of interobserver error. If this error is too high, the data collected by different observers would not be comparable. The error for the ranked scale developed for the Bushman Canine was about $5 \%$ between two observers (J. IRISH and D. MORRIS). This is much lower than the error reported for several other traits (i.e., convexity of the labial surface of maxillary central incisors, 28\%; NICHOL et al., 1984).

Needless to say, reasonably reliable comparisons with other samples can be performed only with a standardized reference plaque. MORRIS (1975) did not apply the ASU system to his extensive study. However, his data were useful for comparison with those of the Chewa sample because they had been incorporated into a later study which uses the ASU system (HAEUSSLER et al., 1989).

Table 3 compares the total frequency of the Bushman Canine for several populations. 6.3\% of the Chewa sample exhibits the trait, whereas the Central Sotho sample possesses the Bushman Canine $9.4 \%$ of the time. In the San, the frequency is $43.1 \%$. This is markedly higher than in the other African samples. The extreme difference between the San and the other African groups supports the view that the San are either ancestral to (TOBIAS, 1964, 1966), or are a different stock of people from, the other aboriginal Africans (GARN, 1971; NICHOL et al., 1984).

Regarding the different frequency between the Chews and Central Sotho, it appears that a gradient exists between Central and South Africa. According to TOBIAS $(1964,1966)$ and others, San or San-like skeletons are present in Central and East Africa, and the San genome may represent an approximation to the ancestral African genome. Taking this into account, the above gradient is likely to be caused by admixture of the San people, who may be of a great time depth and formerly of a much wider geographical distribution, with other peoples (mainly Bantuspeakers). This scenario, as a whole, agrees with the so-called "Bantu-expansion" model (HIERNAUX, 1968; VAN BAKEL, 1981; EXCOFFIER et al., 1987).

In conclusion, it is hoped that this paper helps fill, to some extent, the great void in African dental characterization. However, to understand the exact distribution of the Bushman Canine, much additional data on the prehistoric and modern samples of African populations must still

Table 3. Occurrence of the Bushman Canine in the Chewa tribe and other populations

\begin{tabular}{lrrl}
\hline Sample & $\mathrm{N}$ & $\%$ & Source \\
\hline Chewa & 158 & 6.3 & present study \\
San & 58 & 43.1 & HAEUSSLER et al. (1989) \\
Central Sotho & 159 & 9.4 & HAEUSSLER et al. (1989) \\
Solomon Islands & 131 & 0.0 & MORRIS (1975) \\
Asiatic Indians & 190 & 0.0 & MORRIS (1975) \\
South African whites & 151 & 0.0 & MORRIS (1975) \\
Papago Indians (USA) & 176 & 0.0 & MORRIS (1975) \\
\hline
\end{tabular}


be acquired.

\section{Acknowledgments}

We wish to express our thanks to Dr. C.G. TURNER II of the Department of Anthropology, Arizona State University for his help and collaboration during this work. Thanks are extended to Dr. T. OGATA, Kagoshima University Dental School, for his encouragement. This study was supported in part by Grant-in-Aid for Scientific Research from the Ministry of Education, Science and Culture in Japan (61740482, 01740482).

\section{抄 録}

中東アフリカ現住民 Chewa 族の上顎におけるブッ シュマン・ケナインについて

\section{佐熊正史・J. D. IRISH ・ D. H. MORRIS}

上顎犬歯の咬合面において近・遠心辺縁隆線, 基 底結節および棘突起が強く発達することにより, 小 臼歯に類似する形態を示すすのをブッシュマン・ケ ナイン (Bushman Canine) と呼ぶ. ORANJE(1937) によって最初に記載され，その後 MORRIS（1975） やTURNERら（1991）が詳細な分類と定義を行った. 本稿では, 中東アフリカに居住する Chewa 族から 得た硬石膏模型（男性82例, 女性76例）を用いて, その上顎犬歯に現われた Bushman Canine をアリ ゾナ州立大学の基準模型をもとに観察した。出現頻 度における性差は, これまでの報告と同様に Chewa 族においても認められなかった。 また，中東アフリ カに居住する Chewa 族の出現率を他のアフリカ南 部の諸集団と比較検討したところ, Chewa 族は低い 值を示すことから, アフリカ南部から中央部に向か うに従って Bushman Canine の出現率が低下する 傾向が認められた。 この事実は, San 族 (Bushman) とバンッー系言語を主として話す人々との混血の結 果と解釈される。なお, Chewa 族の Bushman Canine の出現頻度が San 族に比べ極めて低率である ことにより，San 族の出自母集団は Chewa 族とは 異なると考えられた。

これらいずれの所見からあ，いわゆる“Bantuexpansion ”説の妥当性が示唆された.

\section{References}

COON, C.S., 1962: The Origin of Races. Alfred A. Knopf, New York.

ExCoffier, L., B. Pellegrini, A. SANCheZMAZAS, C. SIMON and A. LANGANEY, 1987: Genetics and history of sub-Saharan Africa. Yrbk. Phys. Anthropol., 30: 151-194.

GALlOWAY, A., 1937: The skeletal remains of Mapungubwe. In: FOUCHE, L. (ed.) Mapungubwe. Cambridge Univ. Press, Cambridge, pp. 127-174.

GARN, S.M., 1971: Human Races. Charles C. Thomas, Springfield, Ill.

GREENBERG, J.H., 1963: The Languages of Africa. Mouton Publishers, The Hague.

HAEUSSLER, A.M., J.D. IRISH, D.H. MORRIS and C.G. TURNER II, 1989: Morphological and metrical comparison of San and Central Sotho. Am. J. Phys. Anthropol., 78: 115-122.

HIERNAUX, J., 1968: Bantu expansion: The evidence from physical anthropology confronted with linguistic and archaeological evidence. J. Afrc. Hist., 9: 505-515.

MORRIS, D.H., 1975: Bushman maxillary canine polymorphism. South Afr. J. Sci., 71: 333-335.

MURDOCK, G.P., 1959: Africa: Its Peoples and Their Culture History. McGraw-Hill Book Co., New York.

NICHOL, C.R., C.G. TURNER II and A.A. DAHLBERG, 1984: Variation in the convexity of the human maxillary incisor labial surface. Am. J. Phys. Anthropol., 63: 361-370.

ORANJE, P., 1934: The dentition of the Bush race. South Afr. J. Sci., 31: 576.

TOBIAS, P.V., 1964: Bushman hunter-gatherers: A study in human ecology. In: DAVIS, D.H.S. (ed.) Ecological Studies in Southern Africa. W. Junk, The Hague, pp. 67-86.

TOBIAS, P.V., 1966: The peoples of Africa south of the Sahara. In: BAKER, P.T. and J.S. WEINER (eds.) The Biology of Human Adaptability. Clarendon Press, Oxford, pp. 111-200.

TURNER, C.G. II and G.R. SCOTT, 1977: The dentition of living Easter Islanders. In: DAHLBERG, A.A. and T.M. GRABER (eds.) Orofacial Growth and Development. Mouton Publishers, The Hague, pp. 229-249.

TURNER, C.G. II, C.R. NICHOL and G.R. SCOTT, 1991: Scoring procedures for key morphological trait of the permanent dentition: The Arizona State University dental anthropology system. In: KELLEY, M.A. and C.S. LARSEN (eds.) Advances in Dental Anthropology. Wiley-Liss, Inc., New York, pp. 13-31. VAN BAKEL, M.A., 1981: The "Bantu" expansion: 
demographic models. Curr. Anthropol., 22: 688-690.

VAN VALEN, L., 1962: A study of fluctuating asymmetry. Evolution, 16: 125-142.

WAKIMOTO, K., T. TARUMI, Y. TANAKA, E. YAMAMOTO and S. TSUJIYA, 1984: Handbook of the statistical analysis for using a personal computer. Vol. 1, Kyoritsu-Shuppan, Tokyo, pp. 76-86. (In Japanese) [脇本和昌・垂水共之・田中 豊・山本英二・辻谷 将明, 1984 : パソコン統計解析ハンドブック 1. 共立出版, 東京, pp. 76-86

佐 熊 正 史鹿児島大学歯学部口腔解剖第 2 講座

干890 鹿児島市桜ヶ丘 8 丁目 35 番 1 号

Masashi SAKUMA Department of Oral Anatomy, Kagoshima University Dental School 8-35-1 Sakuragaoka, Kagoshima 890, Japan 